\title{
Lucién Hervé
}

\section{España blanca y España negra}

Lucién Hervé

White Spain and Black Spain

\section{Iñaki Bergera}

\author{
Antonio S. Río Vázquez
}

Madrid: Turner, 2019

3 tomos, 244 págs., $21 \times 21 \mathrm{~cm}$.

ISBN: 978-84-17866-01-3
Boletín Académico.

Revista de Investigación y Arquitectura Contemporánea Journal of Research and Contemporary Architecture Escola Técnica Superior de Arquitectura da Coruña

Número · Number: 10 (2020) Páginas . Pages: 84 - 85 Recibido - Received: 28.10.2019 Aceptado · Accepted: 23.09 .2020 Aceptado - Accepted: 23.09.2020

ISSN 0213-3474

elSSN 2173-6723

DOI: https://doi.org/10.17979/

bac.2020.10.0.5773

https://orcid.org/0000-0003-2340-1758

Este trabajo está autorizado por una Licencia Creative

Commons (CC BY-NC-SA) 4.0
El húngaro Lucien Hervé fue uno de los fotógrafos de arquitectura más reconocidos del siglo pasado, especialmente por su prolongada colaboración con Le Corbusier, que contó con su hábil mirada para retratar gran parte de sus obras, dando como resultado bellas imágenes llenas de fuerza e intensidad, que le abrieron el camino hacia otros encargos y favorecieron su afición personal por explorar con su cámara los grandes monumentos y las construcciones vernáculas de distintos lugares de Europa.

El interés de Iñaki Bergera por investigar sobre la relación entre fotografía y arquitectura moderna le llevó a liderar un exhaustivo y riguroso proyecto de investigación sobre la concreción de ese binomio en España y a indagar posteriormente sobre las conexiones que los principales fotógrafos de la modernidad tuvieron con nuestro país, incluso en aquellos proyectos personales que, por distintas razones, quedaron en su momento inconclusos, como el caso que ahora se presenta en una cuidada edición de Turner en colaboración con el Ministerio de Fomento, que cuenta con la amplia experiencia de Bergera como editor científico y se organiza en tres tomos publicados conjuntamente.

En el primero de ellos, el editor nos detalla el origen del proyecto y expone cómo se fue desarrollando, gracias a la información facilitada previamente por Silvia Blanco, Alicia Marsans y Adolfo Estrada, e invitándonos a hacer un recorrido por las publicaciones sobre fotografía y arquitectura mediterránea durante la primera mitad del siglo, mediante las aportaciones del historiador del arte especializado en fotolibros Horacio Fernández.

El segundo tomo, "Arquitectura popular española”, se abre con un ensayo de Marco Iulano y explica la aproximación de Hervé a los temas
The Hungarian Lucien Hervé was one of the most recognized architecture photographers of the last century, especially for his prolonged collaboration with Le Corbusier, who wanted his camera to portray much of his works, resulting in images full of strength and intensity, which opened the way for other commissions and guided his personal fondness for exploring with his camera the great monuments and vernacular constructions of different parts of Europe.

Iñaki Bergera's interest on investigating the relationship between photography and modern architecture led him to lead an exhaustive and rigorous research project on the concretion of that binomial in Spain, and to subsequently investigate the connections that the main photographers of modernity had with our country, even in those personal projects that, for different reasons, were left unfinished at the time, such as the case that is now presented in a careful edition of Turner in collaboration with the Spanish Ministerio de Fomento, is organized into three differentiated volumes and has Bergera's extensive experience as research editor.

In the first one, the editor details the origin of the project and exposes how it was developed, thanks to the information previously provided by Silvia Blanco, Alicia Marsans and Adolfo Estrada, and allows us to take a tour over the publications on photography and Mediterranean architecture in the first half of the century, through the contributions of art historian specialized in photobooks Horacio Fernández.

The second volume, "Arquitectura popular española", opens with an essay by Marco Iulano and explains Hervé's approach to the themes 


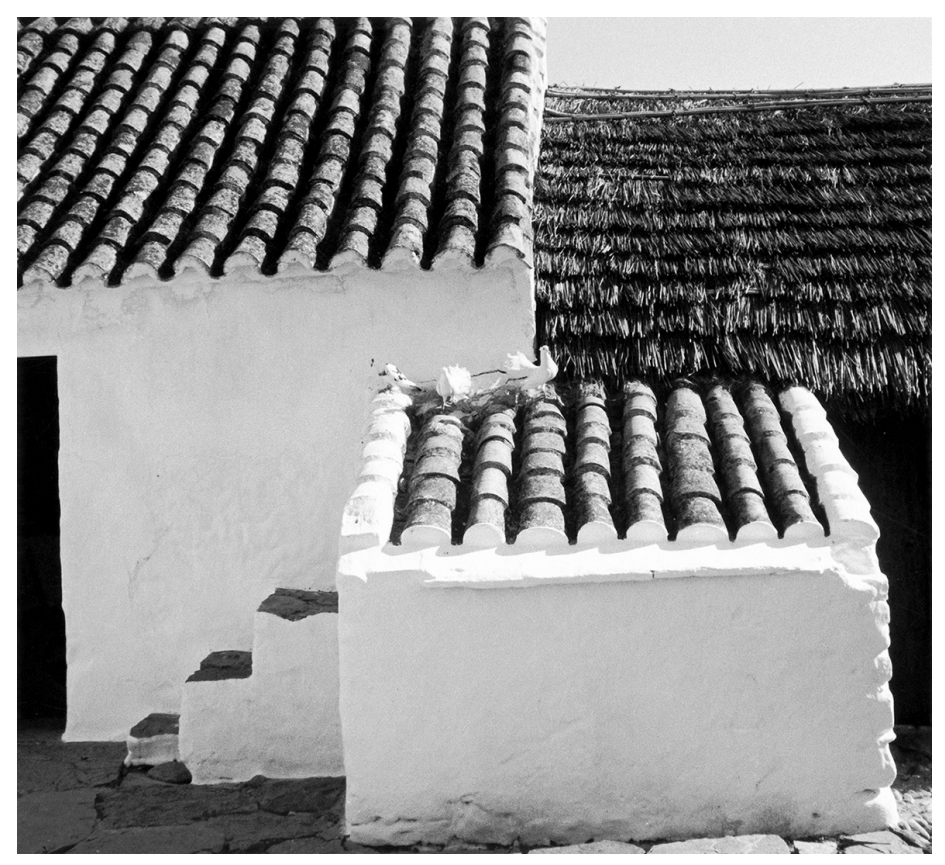

> Lorca, Murcia. Fotografía de Lucien Hervé (1959) Lorca, Murcia. Photography by Lucien Hervé (1959).

$\checkmark$ Portada Cover

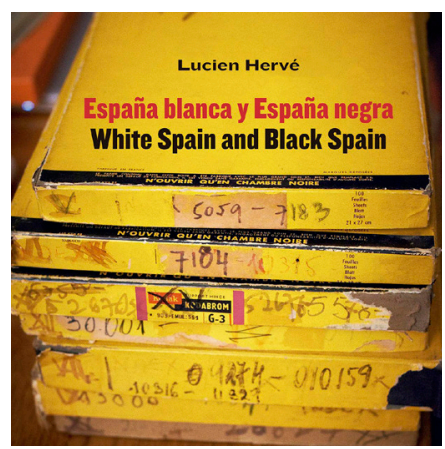

de arquitectura popular mediterránea, con instantáneas tomadas en su mayor parte en Málaga, Almería y las islas Baleares. Nos revela construcciones encaladas, anónimas y solitarias que se tornan majestuosas bajo la mirada del fotógrafo, que traslada su conocimiento pictórico a las composiciones en blanco y negro.

El tercero, titulado "El Escorial”, comienza con las reflexiones de Javier Mosteiro sobre el conjunto monumental y su representación, y nos descubre otra mirada del fotógrafo contemporánea a la anterior y, al mismo tiempo, cercana y distinta. Frente a la luz mediterránea, aquí son las sombras, especialmente las arrojadas, las que llenan de potencia las páginas. Las categóricas piedras escurialenses contrastan con la tersura de la cal, reforzando el discurso visual con breves sentencias de grandes pensadores de la historia acerca de "El símbolo", "La fe", "La regla”, "El siglo” y “El mundo del arquitecto” y "El otro mundo".

La maquetación de las imágenes siguiendo el concepto y los contenidos propuestos por Hervé nos aproxima todavía más a su visión original, legándonos un excelente documento que nos descubre no solo imágenes en gran medida desconocidas, si no el valor de la narrativa en sus proyectos y su manera de entender la fotografía de arquitectura. Aspectos que hoy podemos comprender y disfrutar gracias a la labor de búsqueda y recuperación emprendida por Iñaki Bergera y que tiene en este libro uno de sus mayores logros. of Mediterranean popular architecture, with snapshots taken mostly in Malaga, Almeria and the Balearic Islands. It reveals whitewashed, anonymous and lonely buildings that become majestic under the eyes of the photographer, who transfers his pictorial knowledge to black and white compositions.

The third, entitled "El Escorial", begins with Javier Mosteiro's reflections on the monumental complex and its representation, and reveals another way of seeing of the photographer, contemporary to the previous one and, at the same time, very close and different. In front of the Mediterranean light, here are the shadows, especially the thrown ones, which fill the pages with intensity. The categorical stones of the building contrast with the smoothness of the lime, reinforcing the visual discourse with brief sentences of great thinkers of history about "The symbol", "Faith", "The rule", "The century" and "The world of the architect" and "The other world".

The layout of the images following the concept and content proposed by Hervé brings us even closer to his original vision, leaving us an excellent document that reveals not only largely unknown images, but also the value of the narrative in his projects and his way of understanding architectural photography. Aspects that we can understand and enjoy today thanks to the research and recovery work undertaken by Iñaki Bergera and which has in this book one of his greatest achievements.

Cómo citar · Citation

Río Vázquez, Antonio S. Reseña de Lucién Hervé. España blanca y España negra, de Iñaki Bergera, ed. BAC Boletín Académico . Revista de investigación y arquitectura contemporánea, no. 10 (2020): 84-85. https://doi.org/10.17979/bac.2020.10.0.5773 